\title{
PROSPEK ISLAM DALAM MENGHADAPI TANTANGAN ZAMMAN
}

\author{
Sophia Azhar \\ Fakultas Tarbiyah dan Keguruan \\ Universitas Islam Negeri Alauddin Makassar \\ Jl. H. M. Yasin Limpo No. 36 Samata, Gowa
}

\begin{abstract}
Geo-politics that can contribute to the role of Islam as a socio-cultural system is expected to increase from natural resources in countries that are predominantly Muslim, or officially call themselves Islamic countries. On the other hand there is still anxiety considering the backwardness of Muslims themselves, both in the field of science and technology, in addition to the blurring of Muslims in providing Islamic perceptions, or a kind of distortion of values that engulf the poverty that crippled the power of reason and creativity of Muslims; coupled with less obvious divisions, reasons and interests among Islamic leaders in some predominantly Islamic countries, which can assume the inability of Islamic leadership. One of the dilemmas facing Islamic society in the modernization process is how to place its religious values and orientation amidst rapidly changing changes in social life. On the one hand Muslims want to follow the motion of modernization and present themselves as a modern society, but on the other hand it still wants to not lose its personality traits that are marked by various values that have been embraced. In this kind of transition, there is often an attempt at orientation jumping, leaving behind a new, established value system, capable of being used as a necessary measure of insight and attitude, a personality distortion that brings about the stability of social life. It is important to seek the placement of religious values (Islam), in the process of modenisation and the process of social change with a more open, dialogical and contextual approach.
\end{abstract}

Keywords: Prospect, Islam, Challenges of the Age

\section{PENDAHULUAN}

alau kita telah mengatakan, bahwa agama Islam itu agama pemungkas atau
agama terakhir yang berlaku dimana saja dan kapan saja, maka itu berarti
keyakinan kita juga, bahwa agama Isam itu dapat memberikan pedoman dasar, memberikan bimbingan dan memberikan pemecahan-pemecahan masalah prinsip yang dihadapi umat manusia sepanjang zaman. Logika demikian memberikan konsekuensi implementatif kepada umat Islam, untuk dapat membuktikan dan mengangkat nilai-nilai Islam dalam realitas kehidupan, tanpa melakukan penyeberangan dari wilayah keislamannya, tapi juga tidak melakukan sikap-sikap konyol yang menempatkan umat Islam dalam posisi terbuang kepinggiran daerah cagar budaya. Dalam membahas masalah ini, perlu ada pembedaan pengertian, antara lain, Pertama: Islam sebagai AdDyin, yang mempunyai kompetensi ajaran yang dianggap mampu menjadi agama dunia 
sepanjang zaman, yaitu adanya vitalitas, totalitas dan universalitas dalam Islam. Kedua: Islam sebagai Hadlarah, yang dapat mengalami pasang surut sebagaimana watak setiap kultur, semua itu akan tergantung pada umatnya dalam memberikan jawaban-jawaban terhadap setiap tantangan waktu dan tempat yang dihadapi.

\section{PEMBAHASAN}

\section{A. Tantangan yang Kita Hadapi}

Dalam perkembangannya banyak tantangan yang menghadang didepan kita, paling tidak, ada tiga hal yang perlu diperhatikan :

Pertama: Tantangan sosio-ekonomis, yang memberi isyarat bahwa penduduk dunia yang sekarang berjumlah kurang lebih 6 milyard, dimana sekitar 30\%-nya adalah muslim. Sebagian mereka terbesar berada di Negara-negara sedang berkembang atau dibelahan dunia bagian selatan, yang mempunyai ciri-ciri antara lain:

a. Pertumbuhan penduduknya tinggi.

b. Produktivitasnya rendah.

c. Sumber alamnya besar, tapi tidak ikut menikmati.

d. Tingkat kesejahteraannya rendah.

e. Tingkat kematiannya tinggi.

Kedua : Tantangan sains dan teknologi, yang karena kemajuan ilmu pengetahuan dan hasil teknologi terus berkembang, maka corak kehidupan manusia akan terkurung dalam sistem kompleks dari, "business science technology", dengan tujuan menghasilkan produk-produk yang lebih banyak, dengan pekerjaan yang lebih sedikit, sedang unsur emosional dan spiritual tidak masuk dalam wilayahnya, kehidupan demikian menuntut :
a. Adanya super-efesiensi.
b. Adanya standarisasi
c. Adanya spesialisasi yang ketat.
d. Adanya disiplin dan sistematisasi tinggi.

Sistem masyarakat menjadi mekanis, memakai kultural nomor, dan menuju sikapsikap dehumanisasi (al-la Insaniyah), orientasinya materialistic, jauh dari ideal-ideal jangka panjang, apalagi akhirat.

Ketiga: Tantangan etis religious, sebagai korban kehidupan dalam modernisasi materialis, maka konsekuensinya adalah terjadinya suatu pergeseran kemauan masyarakat, dari kemauan alami (natural will) menjadi kemauan rasional (rational will). Dalam proses perubahan ini, kehidupan emosional manusia mengalami erosi, dan berlanjut pada pemiskinan spiritual. Di Negara-negara maju terjadi kesenjangan antara manusia dengan Tuhannya; dan di Negara-negara berkembang terjadi kesenjangan antara orientasi keagamaan dengan tuntutan duniawinya. Kehidupan rohaniyah menjadi semu dan kelabu yaitu tidak jelas warna dan garisnya. Hal demikian tidak terkecuali juga umat Islam. Disamping tiga macam tantangan tersebut, masih ada lagi tantangan 
lain yang akan dihadapi, seperti krisis ekologi, kependudukan dan ketidak-seimbangan (disequilibrium antara agama dan dunia) dan lain-lain.

\section{B. Kondisi Internal Islam dan Umatnya}

Islam sebagai Ad-Diyn, sebenarnya telah memberikanruang yang cukup luas untuk pemecahan-pemecahan masalah tersebut, baik dalam bentuk "etis" maupun dalam bentuk "sistem". Tentunya Islam sebagai agama yang mencakup waktu dan tempat yang luas, tidak usah memberikan "teori teknis", terhadap setiap masalah, sebab hal demikian akan mengecilkan arti Islam itu sendiri.

Masalah yang sebenarnya memprihatinkan adalah kualitatif umat Islam, suatu kumpulan manusia yang sebanyak itu banyak yang belum menampilkan potensi riilnya malah banyak diantaranya yang dikenal sebagai mayoritas disuatu Negara, tapi mayoritasnya masih terbatas pada "numerical majority" (mayoritas angka), dan pada hakikatnya masih tetap dalam "energetical minority" (minoritas dalam kekuatannya).

Kenyataan semacam ini memang pahit dirasakan dan diantara sebab-sebab yang gampang dilihat antara lain adalah karena :

a. Kekurangan fahaman terhadap hakikat ajaran Islam, karena pengaruh orientasi Barat yang sengaja mengacaukan pengertian-pengertian tentang Islam, dan juga karena sistem pendidikan Islam yang belum mapan.

b. Sikap sinis terhadap Islam, karena kekecewaan melihat realitas umat Islam dalam keterbelakangan, baik keilmuan, teknologi, ekonomi, dan lain-lain.

c. Melemahnya semangat dan idealisme umat Islam, akhibat kegagalan yang berulang-ulang dalam perjuangan politik yang memang belum memiliki strategi baku.

d. Dakwah Islamiyah yang kehilangan aktualitasnya, karena kurang menemukan relevansi dengan tuntutan dan perkembangan yang terjadi dalam realitas sosial yang dihadapi.

\section{Antara Harapan dan Kecemasan}

Jika kita memperhatikan potensi Islam baik dalam vitalitas, totalitas, dan universalitas Islam yang dibutuhkan masyarakat manusia sekarang dan masa mendatang, kiranya ada harapan tenang dalam cakrawala Dunia Islam. Sistem yang dimiliki oleh Islam dapat diharapkan menjadi alternative paling baik dari lainnya yang sudah terasa dalam kepengapan. Hal ini dapat ditambah lagi dengan letak strategis kawasan Islam mulai dari Selat Bosporus sampai kepulauan Indonesia dalam lintasan dalam menggalang potensi umat.

Islam pada masa sekarang dan mendatang, mendapatkan peluang untuk tampil sebagai agama yang dapat memberikan konsep-konsep pemecahan kemelut global dunia modern ini. Namun umat Islam belum menemukan kualitas diri yang dapat mengangkat pamornya sebagai kekuatan dunia, yang dengan kecerahan dan keramahannya menyuguhkan konsepsinya sebagai agama pemungkas 
Memang sedang terjadi fatwah baina al-Islam wa al-muslimin, ada kesenjangan dalam dunia Islam, antara agama Islam dan umatnya. Untuk izzu al-Islam wa alMuslimin, dituntut langkah-langkah strategis dalam usaha meningkatkan mutu atau kualitas umat Islam.

\section{Pendidikan Islam dan Kemajuan Sains}

\section{Refleksi Historis Menuju Milenium Baru}

Pendidikan Islam mempunyai sejarah yang penting. Dalam pengertian yang seluas-luasnya, pendidikan Islam berkembang seiring dengan kemunculan Islam itu sendiri. Dalam konteks masyarakat Arab, dimana Islam itu lahir dan pertama kali berkembang, kedatangan Islam lengkap dengan usaha-usaha pendidikan untuk tidak menyebut sistem merupakan transformasi besar. Sebab masyarakat pra-Islam pada dasarnya tidak mempunyai sistem pendidikan formal.

Pada masa awal perkembangan Islam, tentu saja pendidikan formal yang sistematis belum terselenggara. Pendidikan yang berlangsung dapat dikatakan umumnya bersifat informal; dan inipun lebih berkaitan dengan upaya-upaya dakwah Islamiyah penyebaran dan penanaman dasar-dasar kepercayaan dan ibadah Islam. Dalam kaitan itulah bisa dipahami kenapa proses pendidikan Islam pertama kali berlangsung di rumah sahabat tertentu; yang paling terkenal adalah Dar' al-Arqam. Tetapi ketika masyarakat Islam sudah terbentuk, maka pendidikan dislenggarakan di Masjid. Peroses pendidikan pada kedua tempat ini dilakukan dalam halaqah, lingkaran belajar.

Pendidikan formal Islam baru muncul pada masa lebih belakangan,yakni dengan kebangkitan madrasah. Secara tradisional sejarahwan pendidikan Islam, seperti Munir ud-Din Ahmed, George Makdisi, Ahmad Syalabi, dan Michael Stanton menganggap, bahwa Madrasah pertama didirikan oleh Wazil Nizham al-Mulk pada 1064; Madrasah ini kemudian terkenal sebagai Madrasah Nizham al-Mulk. Tetapi penelitian lebih akhir, misalanya yang dilakukan Richard Bulliet mengungkapkan eksistensi madrasahmadrasah lebih tua di kawasan Nishapur, Iran pada tahun sekitar 400/1009 terdapat Madrasah di wilayah Persia, yang berkembang dua abad sebelum Madrasah Nizhamiyyah (Bulliet, 1972;48) yang tertua adalah Madrasah Miyan Dahiya yang didirikan Abu Ishaq Ibrahim Ibn Mahmud di Nashapur. Pendapat ini didukung oleh sejarahwan pendidikan Islam, Naji Ma'ruf, yang menyatakan bahwa di Khurasan telah bekembang Madrasah 165 tahun sebelum kemunculan Madrasah Nizhamiyyah (Ma'ruf,1973:8). Selanjutnya al-‘Al mengemukakan pada masa Sultan Mahmud alGhaznawi berkuasa(388-421/998-1030) juga terdapat Madrasah Sa'idiyah.

Stanton menyebut madrasah sebagai "the institution of higher learning-lembaga keilmuan (pendidikan)tinggi. Jika ini diartikan sama dengan "universitas"sebagai universitas litteranum atau universitas magistorum yakni lembaga pendidikan yang mengembangkan pendidikan bebas berdasarkan nalar-maka pandangan itu agaknya keliru. Lebih jauh lagi, dalam tradisi pendidikan Islam, institusi pendidikan tinggi lebih dikenal dengan nama al-jami'ah, yang tentu saja secara historis dan kelembagaan 
berkaitan dengan masjid Jami' masjid besar tempat berkumpul jama'ah menunaikan shalat Jumat. Al-jami'ah yang muncul pada awal dengan pretensi sebagai "lembaga pendidikan tinggi" adalah al-Azhar di Kairo, Zaituna di Tunis dan Karawiyyin di Fez. Tetapi,lagi-lagi al-jami'ah ini diakui oleh banyak kalangan Barat sekalipun sebagai ":universitas-univesitas" tertua di muka Bumi, setidaknya sampai dilakukannya pembaharuan dalam dasawarsa silam-lebih tepat disebut sebagai "madrasah tinggi" ketimbang"universitas".

Namun penting dicatat, lembaga-lembaga pendidikan Islam, apakah Madrasah sekalipun menyelenggarakan "advanced education"ataupun al-jami'ah yang memang dimaksudkan sebagai lembaga pendidikan tinggi, tidak pernah menjadi universitas yang difungsikan semata-mata untuk mengembangkan tradisi penyelidikan bebas berdasarkan nalar, sebagaimana terdapat di Eropa pada masa modern. Bahkan universitas di Eropa yang akar-akarnya dapat dilacak dari al-jami'ah seperti ditegaskan Stanton berdasarkan penelitian Makdisi (1981 dan 1990) sampai aba ke 18 juga tak bebas sepenuhnya;universitas Eropa abad pertengahan bahkan pada umumnya berafilisasi dengan atau attached(terkait)pada gereja.

Sepanjang sejarah Islam, baik madrasah maupun al-jami'ah diabdikan trutama kepada al-ulum al-Islamiyyah ilmu-ilmu agama, dengan penekanan khusus pada bidang fiqh, tafsir dan hadist. Meski ilmu-ilmu seperti ini juga yang memberikan ruang gerak kepada akal untuk melakukan ijtihad, setidaknya pada masa-masa klasik, jelas ijtihad disitu yang dimaksudkan berpikir sebebas-bebasnya, ijtihad disini lebih bermakna atau pada prakteknya, sekedar memberikan penafsiran "baru"atau pemikiran "independen" yang tetap berada dalam kerangka atau prinsip-prinsip doktrin yang mapan dan disepakati.

Dengan demikian, ilmu-ilmu "non-agama" atau "keduniaan" (profane) khususnya ilmu-ilmu alam dan eksakta yang merupakan akar-akar pengembangan sains dan teknologi sjak awal perkembangan madrasah dan al-jami'ah sudah berada dalam posisi yang marijinal. Meski Islam pada dasarnya tidak membedakan nilai ilmu-ilmu agama dengan ilmu-ilmu non-agama(ilmu-ilmu umum), tetapi dalam prakteknya supremasi lebih diberikan kepada ilmu-ilmu agama. Ini disebabkan sikap keagamaan dan kesalehan yang memandang, ilmu-ilmu agama sebagai “jalan tol” menuju Tuhan. Memang sebelum kehancuran aliran theology Mu'tazilan pada ,masa Khalifah Abbasiyah, al-ma'mun(198-218/813-33), mempelajari ilmu-ilmu umum yang bertitik tolak dari nalar dan kajian-kajian empiris bukan sesuatu yang tidak ada sama sekali dalam kurikulum madrasah. Tetapi dengan "pemakruhan"untuk tidak mengatakan "mengharaman"penggunaan nalar setelah runtuhnya Mu'tazilah, ilmu-ilmu umum yang sangat dicurigai itu dihapuskan dari kurikulum madrasah; mereka yang cenderung dan masih berminat kepada ilmu-ilmu umum itu, terpaksa mempelajari secara sendirisendiri, atau bahkan "di bawah tanah", karena mereka dipandang sebagai ilmu-ilmu 
"subversive" yang dapat dan akan menggugat kemapanan doktrin mapan Sunni, terutama dalam bidang kalam (theology) dan fiqh.

Dengan demikian, jika pada masa sebelum kahalifah Ma'mun, sains untuk tidak sekaligus menyebut "teknologi" mencapai puncak kemajuannya, hampir bisa dipastikan, ini bukan muncul dari madrasah. Kemajuan sains itu lebih merupakan hasil pengembangan dan penelitian individu-individu ilmuwan muslim yang didorong semangat "scientific inquiry" (penyelidikan ilmiah) guna membuktikan kebenaran ajaran-ajaran Al-Qur'an, terutama yang bersifat "kauniyah". Memang terdapat beberapa madrasah al-Thibb (madrasah kedokteran), seperti dikemukakan Faruqi dan Faruqi dalam The Cultural Atlas of Islam (1986;324-5). Tetapi madrasah kedokteran ini tidak dapat mengembangan ilmu kedokteran dengan bebas, karena sering digugat para ahli fiqh (fuqaha) yang misalnya, tidak memperkenankan penggunaan organ-organ mayat sekalipun dibedah untuk diselidiki. Hal yang sama juga terjadi pada rumah sakitrumah sakit riset, seperti yang terdapat di Bagdad dan Kairo. Rumah sakit riset yang didatangi mahasiswa itu, pada akhirnya terpaksa berkonsentrasi pada ilmu kedokteran teoritis dan perawatan.

Karena itu, tak heran kalau Stanton tidak berhasil membuktikan kaitan yang jelas antara lembaga pendidikan Islam dengan kemajuan berbagai kemajuan sains dalam peradaban Islam. Bahkan Makdisi yang menghabiskan hampir seluruh energy dan usianya untuk meneliti sejarah lembaga-lembaga pendidikan Islam dengan cara begitu canggih dan terinci, juga tak bicara tentang kaitan antara madrasah yang disejajarkan dengan "college" (strata I dalam sistem pendidikan Indonesia sekarang), dengan kemajuan sains dimasa dinasti bani Abbasiyyah. Ini tidak aneh, karena kurikulum seluruh madrasah yang ditelitinya sepenuhnya bermuatan ilmu-ilmu agama, yang dalam klasifikasi ilmu sekarang ini termasuk kedalam ilmu humaniora (humanities). Sama dengan Makdisi, Seyyed Hossein Nasr dalam Islamic Sains:An illustrated Study, yang merupakan salah satu magnum opus-nya juga gagal menjelaskan peranan madrasah dalam kemajuan sains Islam. Hanya terdapat beberapa bidang-bidang ilmu yang diharamkan pada madrasah-madrasah Sunni, seperti filsafat dan ilmu pasti sampai pada masa-masa lebih belakangan (Nasr, 1976:17-9).

Kenapa legalisme fiqh atau syari'ah bisa begitu dominan terhadap terhadap lembaga-lembaga pendidikan Islam? Pertama, ini berkaitan dengan pandangan tentang ketinggian syari'ah dalam ilmu-ilmu keislaman lainnya, seperti disinggung di atas. Kedua, secara institusional lembaga-lembaga pendidikan Islam oleh mereka yang ahli dalam bidang-bidang ilmu agama. Mereka, bahkan berhasil membangun struktur akademis yang cukup canggih dan elaborate. Karena itu dalam kelembagaan madrasah yang baik, misalnya, masyyakhat al-Qur'an (professorship-kegurubesaran al-Qur'an) masyyakhat al-Hadist, masyyakat al-Nahu, dan sebagainya. Sebaliknya tidak dikenal, misalnya, masyyakat kimiyya,masyyakhat al-Thibb dan seterusnya dalam struktur akademis madrasah. Lebih jauh, sebagai sebuah kelompok fungsional, para fuqaha' 
terbentuk manjadi kelompok cukup padu karena dukungan institusional lembagalembaga pendidikan Islam itu sendiri, sehingga siap menangkis kemunculan yang dipandang sebagai tantangan kaum ilmuwan (saintis) Muslim tidak mempunyai dukungan institusional; mereka yang disebut terakhir ini terorganisasi hanya sebagai kelompok-kelompok informal yang sangat longgar, seperti misalnya dalam Dar al-Ilm (akademis sains), Bayt al-Hikmah dan lain-lain. Karena itulah para saintis Muslim tidak berdaya menghadapi kaum fuqaha' yang mengklaim legitimasi religious sebagai The guardian of God's given law, pemelihara hukum yang diwahyukan Tuhan.

Faktor ketiga berkenaan dengan kenyataan, bahwa hampir seluruh madrasah atau al-jami'ah didirikan dan dipertahankan dengan dana wakaf baik dari dermawan kaya atau penguasa politik Muslim. Motivasi kesalehan mendorong para dermawan untuk mengarahkan madrasah bergerak dalam lapangan-lapangan ilmu-ilmu agama yang dipandang akan lebih mendatangkan banyak pahala, ketimbang ilmu-ilmu umum yang mempunyai aura "profane" dank arena itu tak terkait begitu jelas denhgan soal pahala. Pada pihak lain, para penguasa politik pemrakarsa pendirian madrasah, apakah karena didorong kepentingan-kepentingan politik tertentu atau motivasi murni untuk menegakkan "orthodoksi" Sunni, sering mendikte madrasah atau al-jami'ah untuk tetap berada dalam kerangka "orthodoksi” itu sendiri, tegasnya dalam kerangka syari'ah.

\section{Kompleksitas Ilmu Islam}

Jika dipandang semata-mata dari sudut keagamaan yang dewasa ini termasuk ilmu-ilmu "profane", dalam batas tertentu agaknya mengandung implikasi posiif. Supremasi itu membuat transmisi syari'ah atau fiqh, yang merupakan salah satu inti Islam, dari generasi-generasi awal Muslim kepada generasi-generasi berikutnya menjadi "lebih terjamin", cuman sayangnya supremasi syari'ah ini tidak berlangsung dalam cara yang lebih dinamis. Seiring dengan semakin tingginya kecurigaan terhadap nalar, transmisi ilmu-ilmu keagamaan tidak dilangsungkan secara kreatif dan imajinatif. Ijtihad, betapapun terbatasnya, dicekik secara sempurna melalui penutupan pintu ijtihad itu sendiri. Akhibatnya, syari'ah atau fiqh yang transfisikan melalui madrasah atau aljami'ah itu tidak lebih dari pada upaya "pengawetan" doktrin-doktrin yang sebagainya sudah usang dan tidak "berbunyi” ketika dihadapkan kepada realitas sosial yang telah berubah. 'Ulama', anak didik dan umat pada umumnya pada gilirannya terbelenggu dan kejumudan dan bahkan kebekuan. Disinilah kemudian lembaga-lembaga pendidikan Islam yang diharapkan menjadi salah satu factor dinamis dalam masyarakat Isam justru menjadi"bastion"(kubu) kemapanan yang dengan gigih membela "kebekuan" pemikiran dan keilmuan.

Tetapi, jka dilihat dalam perspektif lebih luas, supremasi ilmu-ilmu agama menimbulkan dampak yang amat substansial, bukan hanya terhadap perkembangan ilmu pengetahuan Islam, tetapi juga peradaban Islam secara keseluruhan. Secara keilmuan, perkembangan semacam ini menciptakan dikhotominasi dan antagonisasi bebagai cabang ilmu atau bentuk-bentuk pengetahuan dipandang dari perspektif Islam 
pada akhirnya adalah satu. Dalam Islam tidak dikenal pemisahan esensial antara "ilmu agama" dengan "ilmu profane". Berbagai ilmu dan perspektif intelektual yang dikembangkan dalam Islam memang mempunyai suatu hirarki. Tetapi hirarki ini pada akhirnya bermuara pada pengetahuan tentang "Yang Maha Tunggal"-substansi dari segenap ilmu. Inilah alasan kenapa ilmuwan Muslim berusaha mengintegrasikan ilmuilmu yang dikembangkan peradaban-peradaban lain kedalam skema hirarki ilmu pengetahuan menurut Islam. Dan ini pulalah alasan kenapa para 'ulama' pemikir , filosof dan ilmuwan Muslim sejak dari al-Khindi, al-Farabi dan Ibn Sina, sampai alGhazali, Nashir al-Din al-Thusi dan Mulla Shadra sangat peduli dengan klasifikasi ilmu-ilmu (Nasr, 1976;13-4). Berbeda dengan dua klasifikasi yang dikemukakan di atas, yakni nilmu-ilmu agama dan ilmu-ilmu umum, para pemikir keilmuan Muslim dimasamasa awal membagi ilmu-ilmu pada intinya kepada dua bagian yang diibaratkan dengan dua sisi dari satu mata koin; jadi pada esensinya tidak bisa dipisahkan. Yang pertama,adalah al-ulum al-naqliyyah, yakni ilmu-ilmu yang disampaikan Tuhan melalui wahyu, tetapi melibatkan penggunaan akal. Yang kedua, adalah al-ulumal-naqliyyah, yakni ilmu-ilmu intelek, yang diperoleh hampir sepenuhnya melalui penggunaan akal dan pengalaman empiris. Kedua bentuk ilmu ini secara bersama-sama disebut al-ulum al-hushuli, yaitu ilmu-ilmu perolehan. Istilah terakhir ini digunakan untuk membedakan dengan "ilmu-ilmu"(ma'rifah) yang diperoleh melalui ilham (kasyf).

Walau terdapat integralisme keilmuan seperti ini, setidaknya pada tingkat konseptual, tetapi pada tingkat lebih praktis, tak jarang terjadi disharmoni antara keduanya, atau lebih tegas lagi antara wahyu dan akal, atau antara "ilmu-ilmu agama" dengan sains. Untuk mengatasi disharmoni ini berbagai pemikir dan ilmuwan Muslim memunculkan klasifikasi ilmu-ilmu lengkap dengan hirarkinya.

Sebagaimana dikemukakan oleh Nasr, al-Khindi agaknya adalah pemikir Muslim pertama yang berusaha memecahkan persoalan ini dalam bukunya Fi Aqsam al-Ulum (jenis-jenis ilmu). Ia disusul oleh al-Farabi, yang melalui Kitab Ihsha al-Ulum (Buku Urutan Ilmu-ilmu) memainkan pengaruh lebih luas dalam hal ini. Tokoh-tokoh lain, seperti Ibn Sina, al-Ghazali dan Ibn Rusyd juga membuat klasifikasi ilmu-ilmu yang pada esensinya mengadopsi kerangka Ibn Farabi dengan sedikit penyesuaian. Al-Farabi membagi ilmu menjadi 5 cabang besar : ilmu-ilmu bahasa, ilmu logika, ilmu-ilmu dasar (seperti aritmetika, geometri), ilmu-ilmu alam dan metafisika, dan ilmu-ilmu tentang masyarakat (seperti hukum, dan theology) (Nasr,1987:60-1).

Ibn Butlan (w 469/1068) mencoba menyederhanakan klasifikasi ilmu-ilmu mejadi 3 cabang besar saja : ilmu-ilmu (keagamaan) Islam, ilmu-ilmu filsafat dan ilmu-ilmu alam, dan kesusastraan. Hubungan antara ketiga cabang ini digambarkannya sebagai segitiga : sisi sebelah kanan adalah ilmu agama, sisi sebelah kiri adalah ilmu filsafat dan ilmu alam, dan sisi bawah adalah kesusastraan (Makdisi, 1981: 75). Sedangkan Ibn Khaldun pa abad 8/14 pada dasarnya kembali kepada pembagian ilmu naqliyyah dan ilmu-ilmu 'aqliyyah. Termasuk kedalam ilmu-ilmu naqliyyah adalah ilmu-ilmu al- 
Qur'an, hadist, fiqh, kalam,tashawwuf dan bahasa. Sedangkan ilmu-ilmu 'aqliyyah mencakup logika dan filsafat, kedokteran, pertanian, geometri, astronomi dan sebagainya.

Terakhir, Shams al-Dhin al-Amuli pada abad 9/15 dalam bukunya Nafa'is alFunun (Unsur-unsur Berharga Sains) setelah mendaftar hampir seluruh cabang ilmu yang berkembang di Dunia Islam memberikan dua klasifikasi. Dalam klasifikasi pertama, ilmu-ilmu terbagi dua : ilmu filosofis dan ilmu-ilmu non-filosofis. Bagian pertama yang terdiri dari ilmu teoritis dan praktis mencakup metafisika, matematika, etika, ekonomi dan politik. Bagian kedua yang terdiri dari ilmu-ilmu keagamaan dan non-agama mencakup ilmu 'aqliyyah dan naqliyyah. Dalam klasifikasi kedua, ilmuilmu terbagi kepada ilmu-ilmu awal (awa'il) dan ilmu-ilmu lanjutan (awakhir). Bagian pertama mencakup ilmu-ilmu semacam matematika, kedokteran, kimia, astronomi, geografi, etika, politik, ekonomi dan sebagaiya. Sedangkan bagian kedua mencakup kesusatraan, ilmu syari'ah, dan tashawwuf, sejarah dan sebagainya (Nasr, 1976 : 15-6).

Apa arti semua klasifikasi yang rumit ini? Ia menunjukkan kompeksitas ilmu-ilmu yang berkembang dalam peradaban Islam ; ia menegaskan bahwa ilmu-ilmu agama hanya salah satu bagian saja dari berbagai cabang ilmu secara keseluruhan. Kemajuan peradaban Islam berkaitan dengan kmajuan seluruh aspek atau bidang-bidang keilmuan. Jadi, tatkala bagian-bagian besar ilmu tersebut "dimakruhkan", terciptalah kepincangan yang pada gilirannya mendorong terjadinya kemunduran peradaban Islam secara keseluruhan.

\section{PENUTUP}

Adalah diluar cakupan tulisan ini untuk membahas pemecahan berbagai masalah amat kompleks yang dihadapi pendidikan tinggi Islam dewasa ini. Proses-proses historis yang ditempuh pendidikan tinggi Islam merupakan cermin yang seyogyanya menimbulkan refleksi, yang pada gilirannya akan menggerakkan upaya-upaya kreatif dalam kerangka membangun kembali peradaban Islam. Tantangan abad ke 21, bagaimanapun menuntut respon yang tepat dari sistem pendidikan Islam secara keseluruhan. Jika kaum Muslimin termasuk di Indonesia tidak hanya ingin sekedar servive di tengah persaingan global yang semakin tajam dan ketat, tetapi juga berharap mampu tampil di depan, maka reorientasi pemikiran mengenai pendidikan Islam dan restrukturisasi sistem dan kelembagaan jelas merupakan keniscayaan. Cara pandang yang menganaktirikan iptek tampak tidak bisa dipertahankan lagi.

Kesadaran awal kearah itu, sudah mulai berkembang pada kalangan pemikir dan penanggung jawab pendidikan Islam di Indonesia. Dr. H. Tarmizi Taher, ketika menjabat Menteri Agama, misalnya, telah dan memasyarakatkan gagasan tentang pengembangan IAIN Jakarta dan Yogyakarta sebagai proyek pilot menjadi "universitas Islam", yang tidak lagi terbatas fakultas-fakultas agama, tetapi juga fakultas-fakultas umum. Sementara gagasan ini tengah dan digodok para ahli yang dikordinasikan 
Departemen Agama, sepatutnyalah kita berharap agar fakultas-fakultas non-agama, yang akan didirikan itu, juga mencakup fakultas-fakultas yang berkenaan dengan sains dan teknologi.

\section{DAFTAR PUSTAKA}

Abdullah, Taufik, Schools and Politics The kaum Muda Movement In Sumatera, Itchaca, M.Y. Cornell University, 1971.

Abdurahman Surjomihardjo (eds). Ilmu Sejarah dan Historiografi. Arab dan Perspektif, Jakarta: Gramedia, 1985.

Abul Majd, Ahmad Kamal, Attajdid wa Rikrussiyas, al-Islamy Manhajan wa Tathbiqon, Makalah Seminar Pemikiran Islam menghadapi Sistem Dunia Baru, Kuwait University, 1981.

Adam, Don, Education and Modernization, Reading, Mas, Addison-Wesley.

Ahmad, Akbars, Descovering Islam: Making Sense of Muslim History and Society, London : Routledge \& Kegan Paul, 1990.

Ahmad, Kursyid, Prinsip-prinsip Pedidikan Islam, Surabaya: Pustaka.

Almadudy, Abul A'la, Waqiul Muslimin wa Sabilun Muhudhi Bihim, Muassasah arRisalah, cetakan II, Beirut, 1978.

Al-Qur'an al-Karim.

Muhammad Tholhah Hasan, Prospek Islam dalam menghadapi Tantangan Zaman. Lantabora press-Jakarta, 2003.

Prof. Dr. Azyumardi Azzra, M.A, Pendidikan Islam Tradisi dan Modernisasi Menuju Mllenium Baru.

Tajdid ad-Diyn Wa Ihya'uhu, Muassasah ar-Risalah Beirut, 1978.

Wajibub Syabab al-Muslim al-Yaum, Al-Maktab al-Islamy, Beirut, 1979. 